\title{
An Arabic source of a famous scene in Hamlet
}

\section{Dr. Mahmoud Mohamed Mekky}

PhD (First Honour) in Translation Studies, Department of English

language and Literature, Faculty of Arts, Cairo University.

lecturer, Department of Languages and Translation, Higher Institute

For Specific Studies, Giza.

mohmoudm@yahoo.com

\begin{abstract}
This research deals with the hypothesis that William Shakespeare was influenced by an Arab source in Hamlet, specifically in the scene of murdering Hamlet the King by dripping poison in his ear while sleeping in the orchard by his uncle Claudius (Act I, v: 59-79). The supposed Arab source that influenced Shakespeare is in one of the oldest Arabic books in prose containing tales on the tongue of animals, i.e., The Book Kalilah and Damnah by Abdullah Ibn al-Muqaffa, which he translated from Palhevi into Arabic in 750, i.e., 851 years before Shakespeare wrote his play in 1601.
\end{abstract}

Key words:

Hamlet-Kalilah and Dimnah -poison- murder- deathShakespeare- north-Ibn al-Muqaffa-

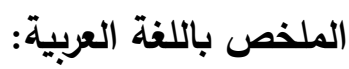

يتاول هذا البحث فرضية تأثر وليم شيكسبير بمصدر عربي فى مسرحية "هاملت"

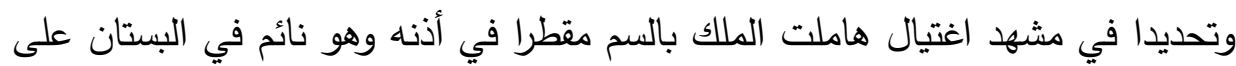

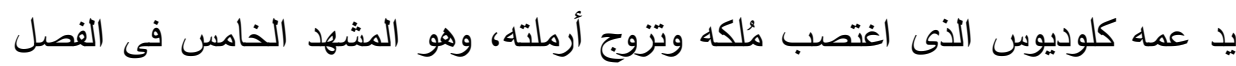
الأول وخاصة الأبيات من 59 حتى 79. والدصدر العربى الدفترض أن شكسبير تأثر الثرا

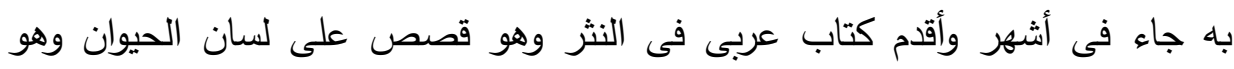

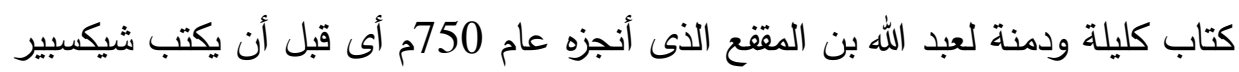

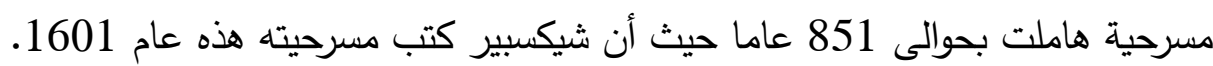
الكلمات الدالة: - الئة

هاملت- اغتيال - كليلة ودمنة- الأسد - الثور - السم- ابن المقفع- شكسبير . 
مجلة وادي النيل للاراسات والبحوث الإنسانية والاجتماعية والتربوية (مجلة علمية محكمة)

(ISSN : 2536 - 9555)

\section{An Arabic source of a famous scene in Hamlet}

\section{1-Introduction}

\section{Dr. Mahmoud Mohamed Mekky}

This research deals with the hypothesis that William Shakespeare was influenced by an Arab source in Hamlet, specifically in the scene of murdering Hamlet the King by dripping poison in his ear while sleeping in the orchard by his brother Claudius (Act I, v: 59-79). The supposed Arab source that influenced Shakespeare is in one of the oldest Arabic books in prose containing tales on the tongue of animals, i.e., The Book Kalilah and Dimnah by Ibn al-Muqaffa, which he translated from Pahlavi into Arabic in 750, about 851 years before Shakespeare's writing of his play between 1599 and1602. Historically, it is known that Shakespeare read works of the historian and Elizabethan English translator Thomas North (1535-1604), who translated Plutarch's Lives of the Noble Grecians and the Romanes from French into English in 1579, the book which was used by Shakespeare as a source of his Roman plays, and which exerted "powerful influence on Elizabethan prose" (Elis \& Okay-Brown 447, Feltcher 180). North was the first English writer who translated The Book of Kalilah and Dimnah into English in 1570, entitled as The Morall Philosophie of Doni through an indirect source (Cooperson 155), and his translation was based on Doni's version which Doni translated from Spanish into Italian in 1552.

\section{2- Sources of Shakespeare's Hamlet}

The critics of Shakespeare agreed that the sources of his play Hamlet, Prince of Denmark, trace back to the pre-13 ${ }^{\text {th }}$ century story. The first and the most important of these sources is Saxo Grammaticus's Historia Danica [The Danish history] (Rasmus 1) which is thought that it was written in 1200 . The book of this Danish historian, Saxo (1160-1220), contained a Scandinavian version of the story of Hamlet who was known as Amleth. It is believed that Shakespeare borrowed the tale of Hamlet from this story to create Hamlet (Elton 106-30, 398-413). This story was translated from Latin into French in 1570 by François de 
مجلة وادي النيل للار اسات و البحوث الإنسانية و الاجتماعية والتربوية (مجلة علمية محكمة)

Belleforest (1530-1583) in his book Histoires Tragiques (Edwards 1-2). Though Edwards says "it does not appear that the Hamlet story was translated into English until 1608"(2). Edwards' statement means that the English translation of de Belleforest came after the two versions of Hamlet whether which was written in 1599 or in 1601; but according to Enani, Shakespeare might have read this French translation in one way or another, or there was another English translation before the 1608 English translation, which might not arrive us (12).

Other literary scholars believed that an earlier play known as the Ur-Hamlet which was performed in 1589, possibly written by Thomas Kyd and now lost, was the main source of Shakespeare's Hamlet. Few scholars said that the Ur-Hamlet is an early draft of Shakespeare's Hamlet itself (Jenkins 82-85).

But no scholar mentions the Arabic sources of Shakespeare's plays, though the influence of Arabic works on the European great writers as Dante Alighieri, Boccaccio and Chaucer-all of them lived before Shakespeare - has been known and proved by the specialist scholars in Islamic studies and Arabic literature as Miguel Asin Palacios in Islam and Divine Comedy (Sutherland 52); moreover, there are many scenes in Shakespeare's plays that can be traced back to Arabic sources not only because of the strong resemblances to the Arabic sources which preceded them, but also because of the materialistic evidences and proofs which they contain, some of these scenes are as follows:

1-the resemblance between the scene in which Macbeth is told by the witches that he will never be defeated until the "Great Birnam wood" moves to the "high Dunsinane Hill" (Macbeth IV: I, 92-94) and Zarqa al-Yamama's legend whose the ability to see riders or walkers from the distance of one week. So the enemies of her tribe who hope to evade Zarqa's gaze and watch decided to hide behind trees which they carried. Zarqa noticed what they did, so she warned her tribe that the trees were moving towards them and these trees hid soldiers, but members of her tribe thought she was going mad and ignore her warning. Eventually, the enemies 
reached her tribe and killed men, then she was captive, the enemies tore out Zarqa's eyes and crucified her, according to Ibn 'Abd Rabbih (III: 71-9).

2-the resemblance in the incidents between Desdemona's handkerchief, the first gift given to her by Othello, which she lost and was found by Iago who persuades Othello to be suspicious of Cassio and Desdemona (Othello, III, iv.58-63), so Othello killed Desdemona, and the tale of the Three Apples" in The Arabian Nights (Alf Layla, 1, 80-84).

3-The resemblance of death of Romeo and Juliet where the former was informed that Juliet was dead so he drank poison when the latter awakens discovering Romeo's death she stabs herself with his dagger and joins his death (V, iii, 171) and the death of Mai and Mudad al-Jurhomi in the pre-Islamic legend (Ibn Munabbih 111).

\section{3- The Arabic source of a famous scene in Hamlet}

Moreover, there are two scenes in Hamlet supposed to be traced back to Arabic sources; the first is the way of Hamlet the king's death by dripping poison in his ear. This scene is very similar to a scene in The Book of Kalilah and Dimnah, in the chapter of "the lion and the bull", specifically in the tale of "the whoremistress and her slave girl's lover".

The second scene is the resemblance, in Hamlet, between sending Hamlet by Claudius to the king of England with a sealed letter instructing the king of England to kill Hamlet (Hamlet, IV: iii, 40-44) and the death of the prominent pre-Islamic poet Tarafa Ibn al-'Abd (543-569) and Al-Mutalammis who were sent by Amr Ibn Hind the king of Hyra to the governor of Bahrayn with sealed letters asking the governor to kill them (Nickolson 107).

Here, I will treat the resemblance between the way of death of Hamlet the king by poison and the way of death of the slave girl's lover by poison in Kalilah and Dimnah. The researcher will focus on former scene in Hamlet to prove how the Arabic source reached to Shakespeare. How did this Arabic tale reach Shakespeare? Firstly, how the tale is narrated in the three sources: 
مجلة وادي النيل للار اسات و البحوث الإنسانية والاجتماعية والتربوية (مجلة علمية محكمة)

\section{4- The tale in the three sources}

The oldest of the three sources which in Ibn al-Muqaffa's Kalilah wa Dimnah that he translated in 750.

\section{A-The tale in Kalilah and Dimnah}

In al-Yazji's version of Kalilah and Dimnah the tale goes as follows

$$
\begin{aligned}
& \text { ومضى [الناسك] حتى دخل إحدى المدن فلم يجد فها قِرى إلا بيت امرأة فاجرة، }
\end{aligned}
$$

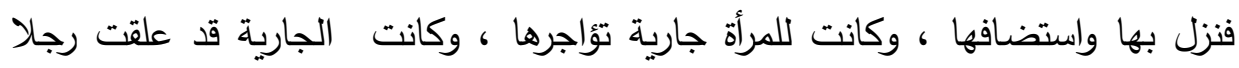

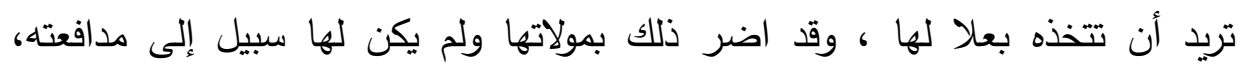

$$
\begin{aligned}
& \text { فاحتالت لقتله فى تلك الليلة التى استضافت فيها الناسك، ثم إنّ الرجل وافى فسقته من } \\
& \text { الخمرة حتى سكر ونام، فلما استغرق فى النوم ونام فى البيت، عمدت إلى سم كانت قد }
\end{aligned}
$$

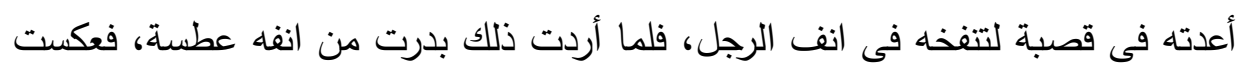

$$
\begin{aligned}
& \text { السم إلى حلق المرأة فوقعت ميتة". }
\end{aligned}
$$

(Yazji 126)

[so the monk went on and entered a city, he did not any lodging nor shelter, except at a whore's house. The woman had a slave girl whom she used to hire out, but that girl has fallen in love with a man and did not want to have any other. That made troubles to the woman, so she schemed to kill him. So she gave the lover unwatered wine to make lose his sense. When he fell asleep, the woman placed the poison which she has prepared in a hollow reed, so she could blow it into the man's nostrils, putting one end of the reed into the man's nose and the other in her own mouth. Before she had a chance to blow in the reed, the man sneezed and the poison blew into the woman's throat, so that she fell down dead] (Irving 13-14). 
مجلة و ادي النيل للار اسات و البحوث الإنسانية و الاجتماعية والتربوية (مجلة علمية محكمة)

(ISSN : 2536 - 9555)

\section{B-The tale in North's Fables of Bidpai}

While the tale in North's Fables of Bidpai is entitled in the contents as "A bawd trying to blow poison into a young man's ear, swallows it herself and dies"

Then the tale follows as

And having prepared already a quill which me had fylled with fine venimous beaten powder, shee went and put it to the mouth of this sleeping Cocke, and blewe at one of the endes to make it enter perforce into the body. But it happened farre otherwise than shee looked for. For even at that instant there came such a blast of winde from him that had the oppium, that me having hir mouth ready to blowe, received with the force of his winde the whole powder into hir owne bodie, which was made so strong that forthwith shee fell downe dead (Jacobs lxxiii,106-107).

\section{C- The tale in Shakespeare's Hamlet}

The scene of murder Hamlet the king by poison dripping in his ear as it is narrated by the ghost is as follows

Brief let me be. Sleeping within my orchard,

My custom always of the afternoon,

Upon my secure hour thy uncle stole

With juice of cursed hebona in a vial,

And in the porches of my ears did pour

The leperous distilment (Act I, v: 59-66).

By comparing these three tales, there are common features between them

1-some person was killed by poison

2- The victim was killed while he was sleeping or lost conscious

3- the murderer in the first and second tales is a woman, while he was a man in the third.

4- in the three tales poison was dripped with a hollow reed. 
مجلة وادي النيل للار اسات والبحوث الإنسانية والاجتماعية والتربوية (مجلة علمية محكمة)

But by comparing the first and last tales in detail, it is clear that there are important similarities between them

\section{4- Similarities and differences between the murder of Hamlet the king and death of the slave girl's lover}

\section{1-The similarities}

Actually, the two tales are about the way of death of Hamlet the king by dripping poison in ear by his brother and the way of death the slave girl's lover by placing poison in his nose by a hollow reed while he was lost conscious.

The resemblances between the two tales are as follows

1 -the dead in both tales were killed by poison by using a hollow reed.

2- There was a conspiracy in both tales a brother in the first and a whore in the second.

\section{2-The differences}

1 -in the first the murderer was successful, but in the second the murderer failed and she killed her self

2-in the first the murder was sleeping in the orchard and in the second the murder lost conscious by drinking him "unwatered wine"

3-in the first the killer just drips poison in the victim's ear, while in the second she blew the hollow reed in the murder's nose, so by putting one end of the reed into the man's nose and the other in her own mouth. Before she had a chance to blow in the reed, the man sneezed and the poison blew into the woman's throat, so that she fell down dead (Irving 13-14).

\section{5-How the Arabic tale reached Shakespeare}

Thomas North was the first English writer who translated The Book of Kalilah and Dimnah into English in 1570, entitled The Morall Philosophie of Doni (Cooperson 155). According to Joseph Jacobs this means that the first English version of Kalilah and 
Dimnah was taken from an Italian translation of the book; the Italian rendition was from Spanish; the Spanish translation was from Latin; the Latin adaptation was from Hebrew, and the Hebrew translation was taken from Arabic (xi).

Jacobs in his detailed introduction to North's translation asserts that The Morall Philosophie of Doni "comes as a happy medium between the stateliness of his Guevara and grandeur of his Plutarch, with its Italian vivacity tempered with far off echoes of oriental gravity" (lv). Then, he adds the features of North's style as follows: Firstly, North "departs more free from the Italian version" (lvi). Secondly, he comments on the flexibility of North's style. Thirdly, "some of his words are obsolete". The Book of Kalilah and Dimnah arrived relatively late to English. Finally, The Cambridge History of the English and American Literature describes North that was neither a "schoolman" nor a "euphuist", but he freed "his language from the fetters which immature scholars had cast upon it" (IV: 13). Moreover, it adds "above all, his style had a dramatic quality which suggests to the reader a constant movement, and the value of which, no doubt, was candidly recognized by Shakespeare" (IV:12). Moreover, North's translation of Kalilah and Dimnah is characterized by its "good, plain prose, telling the stories with some degree of verve, and slowing to a more sententious discourse for his moral conclusions" (Stevenson 405).

\section{5-Conclusion}

It is known that the influence of the Arabic science and Arabic literary books on the European Renaissance began from the twelfth century with the translation of the Arabic works into Latin and into Castilian in Toledo led and sponsored by Raymond of Toledo and Alfonso $\mathrm{X}$ of Castile in the twelfth and thirteenth centuries respectively. So there are two important translations of Kalilah and Dimnah into European languages as Müller says; one was in the eleventh, a second in the thirteenth century (160). The first of them was done from Arabic into Greek by the Jewish Symeon, the son of Seth, in 1088 under the title "Stephanites and Ichnelates" (157). 
مجلة وادي النيل للاراسات والبحوث الإنسانية والاجتماعية والتربوية (مجلة علمية محكمة)

This Greek version of Kalilah and Dimnah was translated into Italian in 1583 by Giulio Nuti (Müller 160; Jacobs 1xxx).

The other was John of Capua's translation of Kalilah and Dimnah from Rabbi Joel's Hebrew translation (taken directly from Arabic in 1250) into Latin between 1263 and 1278 as Directorium Humanae Vitae. This Hebrew translation, according to Cooperson, "served as the basis for versions in German in 1480, Spanish in 1493, and Italian" in 1552, and the Italian was translated into English in 1570 and it became the basis for the first English translation in 1570 by North who translated it into Elizabethan English: The Fables of Bidpai: the Morall Philosophie of Doni (155).

So it is supposed that Shakespeare has read Kalilah and Dimnah in North's English translation; because, Shakespeare has read North's Plutarch's Lives and used it as a main source for his Roman plays, i.e. Julius Caesar and Romeo and Juliet. So it is not eccentric that Shakespeare used the tale of "a bawd trying to blow poison into a young man's ear, swallows it herself and dies" which is North's book as a source of murdering Hamlet the king by poison in Hamlet. Finally, though North's book is an adaptation of the Arabic tale, the Arabic spirit is clear in North's tale.

\section{Reference}

Alf Laylah wa Layah (The Arabian Nights) (2001), vol. I, Madbouly library, Cairo.

Al-Yazji, Khalil ed. (1888) Kalilah wa Dimnah. Syria.

Cooperson, Michael (2005) "Ibn al-Muqaffa." Dictionary of Literary Biography: Arabic Literary Culture 500 - 925. 1st ed. Vol. 311. Ed. Michael Cooperson, Shawkat M. Toorawa and Thomson Gale. U.S.A.,.150-163.

Edwards, Phillip, ed. (1985). Hamlet, Prince of Denmark. New Cambridge Shakespeare. Cambridge 
مجلة وادي النيل للاراسات والبحوث الإنسانية والاجتماعية والتربوية (مجلة علمية محكمة)

(ISSN : 2536 - 9555)

Ellis, Roger \& liz Okay-Brown (2008) "British Tradition", Routledge Encyclopedia of Translation.2nd ed., eds. Mona Baker and Gabriela Saldanha. Routledge, 333-247.

Elton, Oliver; powell, Frederick (1905) The Nine Books of the Danish History of Saxo Grammaticus in Two Volumes, Norroena Society.

Enani, Mohamed. Trans \&ed. (2004), Maasat Hamlet, the Public Egyptian organization of the Book.

Jeffers, A. N., ed. (2004) Hamlet, William Shakespeare, York Press, Beirut.

Jenkins, Harold (1982), Hamlet, The Arden Edition of the Works of William Shakespeare, Muthuen, London \& New York, 82-85

Fletcher, W. G. D. (1895), Dictionary of National Biography, ed. Sidney Lee, Vol. XLI, Macmillan and Co. New York \& London.

Jacobs, Joseph, ed. (1888), The Earliest English Version of the Fables of Bidpai: The Morall Philosophie of Doni. Vol.3. D. Nutt.

Ibn 'Abd Rabbih (2004), Al-'Iqd al-Farīd (The Unique Necklac), Hayat Kusor althakafa, Cairo.

Irving, Thomas Ballantine, trans.(1980), Kalilah and Dimnah. Juan de la Cuesta,

Nicholson, Reymond A., (1907) A Literary History of the Arabs.

Palacois, Meguel Asin, Islam and Divine Comedy 1919, trans. Harold Sutherland, 1926, London.

Ramus, Petrus, (1839) Saxonis Grammatici Historia Danica, Havniae, Denmark.

Shakespeare, William (2001), The Complete Works of Shakespeare, Glasgow.

Stevenson, Jane. "The Moral Philosophy of Doni, popularly known as the Fables of Bidpai (review)." University of Ttoronto Quarterly 74.1 (2004): 404-405.. Retrieved March 4, 2014 from, http://muse.jhu.edu/ journals/utq/summary/v074/74.1stevenson_j01.html>

Wahb Ibn Munabih, (1978) Al-Tijan, ed. Krenekow, Sanaa. 